\title{
Does it pay off? The effects of party leadership elections on parties' trustworthiness and appeal to voters
}

Bram Wauters \& Anna Kern

\begin{abstract}
In the last few decades, political parties in several Western countries have opened up the process of leadership selection to all party members. So far, research has mainly focused on the drivers of this development, taking into account both internal factors (reducing power of middle-level party elites) and external factors (increasing the party's attractiveness). Only few studies have tested the effects of these external arguments. In this study, we investigate whether parties that select their leader inclusively (1) exhibit higher levels of trustworthiness, and are more appealing to (2) voters and (3) potential members. Based on the procedural fairness argument, we expect a positive effect of inclusive procedures. We conduct a vignette experiment with fictional parties and find that inclusive selection procedures do not strengthen citizens' perceptions of trustworthiness. Moreover, citizens are not more willing to vote or join parties with inclusive selection procedures.
\end{abstract}

Keywords: parties, intra-party democracy, leadership selection, procedural fairness, experimental research 


\section{Introduction}

In many established democracies, party leaders are among the most important actors in political decision-making. Evidently, their selection is a crucial decision with large implications. In the last few decades, numerous political parties have opened up the selection procedure of their leaders to all party members. While in countries such as Spain, Denmark, Norway, Austria and Romania, none or only a handful of parties use inclusive selectorates, in the UK, Israel, Belgium, Canada and Portugal it has become common practice amongst almost all parties (Pilet \& Cross, 2014). Although this democratization in leadership selection cannot be found in all countries, it nevertheless constitutes a trend (Quinn, 2010; Cross \& Katz, 2013; Pilet \& Cross, 2014; Sandri, Seddone \& Venturino, 2015).

But why did these parties introduce such direct member votes? Apart from internal reasons (strengthening the position of the party leader in the party), external reasons were cited as motivation to introduce such direct member votes (Scarrow, 1999; Lisi, 2010; Wauters, 2014; Gauja, 2017). These external reasons mainly consist in the assumption that leadership elections would raise the party's appeal to voters and (potential) members. However, surprisingly, apart from research on the effect of inclusive leadership selection procedures on the electoral performance of particular parties (Pedersen \& Schumacher, 2015) and on voters' levels of trust in parties in general (Shomer, Put \& Gedalya-Lavy, 2016), the external arguments leading to the introduction of leadership elections have not been evaluated empirically. By setting up an experimental design, we are able to disentangle the effect of the principle of internal democracy from indirect, associated effects such as more media attention and more appealing leadership profiles. In this way, we can determine whether inclusive selection procedures in itself are beneficial for political parties. Rather than focussing on only one success indicator, we adopt a broad approach by including three indicators in this study. We investigate whether parties that allow party members to select their party leader (1) exhibit higher levels of trustworthiness, and are (2) more attractive to future voters and (3) potential party members. Based on the procedural fairness theory (Grimes, 2006) and on the support for more inclusive selection procedures among citizens (Close, Kelbel \& van Haute, 2017), we expect that inclusive leadership selection procedures raise a party's appeal and trustworthiness. Indeed, apart from decision outcomes (and the satisfaction about them), also the nature of decision-making procedures could impact perceptions of parties' trustworthiness and attractiveness (Carman, 2010). Rather than focussing on trust in parties in general (Shomer, Put \& Gedalya-Lavy, 2017), we investigate whether individual parties benefit from organising inclusive leadership contests. The central research question of this paper is therefore threefold: Do inclusive leadership selection methods (1) lead to higher levels of trust in parties that use them? And do they make these parties more attractive to (2) voters and (3) potential 
members? To answer these questions we designed a vignette experiment with fictional parties that allows us to control for several intervening variables. We conducted this survey experiment among Flemish citizens in January and February 2019.

Our study shows that citizens who were exposed to fictional parties with an inclusive selection procedure are not more likely to trust or vote for these parties than citizens who were presented with an exclusive selection procedure. Also with respect to joining a political party, no difference was found between citizens who were exposed to a party with an inclusive selectorate and citizens who evaluated the party profile with the exclusive selectorate. This finding holds both for parties with a rightist ideological profile and for parties with leftist characteristics (which were both separately tested). We hence find that opening up the selection procedure, does not seem to pay off directly for parties: neither in terms of perceived trustworthiness or higher vote share nor in terms of raising party membership.

This paper is structured as follows. First, we review the literature on the concept and causes of party leadership elections. Next, we highlight the few studies that investigated whether democratising leadership elections has produced any external effects. Based on the procedural fairness theory, we then argue that it is likely that more inclusive selectorates result in higher levels of trust in political parties and in an increased propensity to vote for or to join these parties. After setting out the methodology, we present the results of our vignette experiment, and we end with a discussion of the implications of our findings.

\section{Reasons to introduce inclusive procedures for party leadership selection}

Party leaders can be selected in various ways. We focus here on one of the four dimensions initially developed by Rahat and Hazan (2001) to study candidate selection methods, i.e. the selectorate. ${ }^{1}$ The selectorate can be defined as the body that selects the party leader. Selectorates differ in the degree of inclusiveness, which can be measured by looking at the relative size of the group of actors responsible for the selection of the party leader. In order to grasp this variety, Kenig (2009) developed a continuum on which leadership selection methods are classified according to their degree of inclusiveness. On the exclusive extreme of the continuum, a small elite group decides who will become

\footnotetext{
1 The four dimensions include selectorate, candidacy, decentralization and voting system. Since the latter two dimensions are not relevant for leadership selection, i.e. the selection of one single person at the national level, and as we are here not interested in candidacy requirements, we will only discuss the selectorate.
} 
the party leader, while on the inclusive extreme all members (or even all voters) are allowed to make this decision (see Figure 1).

Figure 1: Inclusiveness of leadership selection rules (Kenig, 2009)

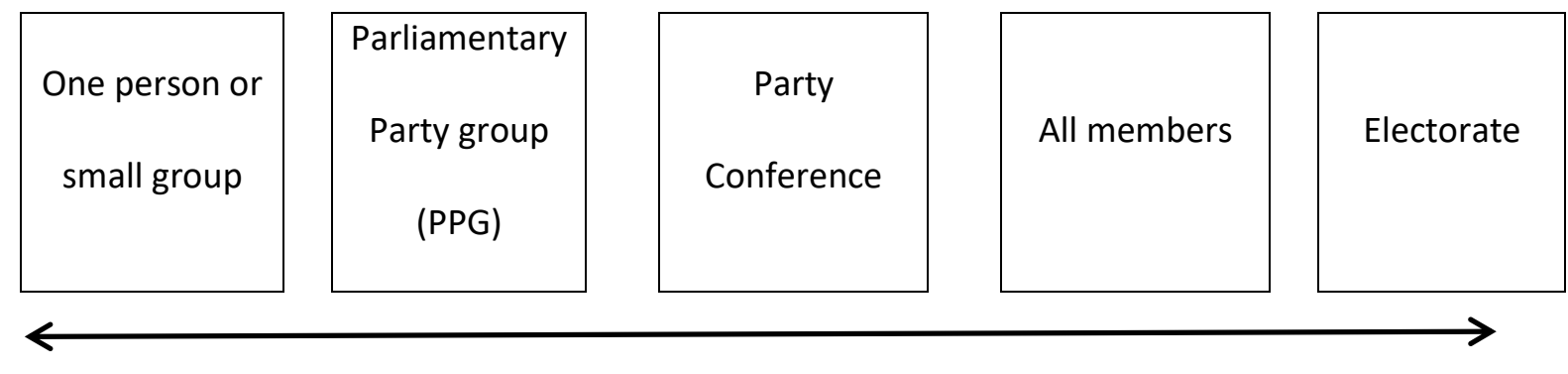

Exclusive

Inclusive

In the past few years, many parties have moved towards more inclusive methods of leadership selection (Pilet \& Cross, 2014; Sandri, Seddone \& Venturino, 2015; Cross and Blais, 2012). In particular, direct member votes to select the party leader are nowadays held in several countries including Belgium, Canada, Israel, the UK and Portugal. They correspond to what Poguntke et al (2016) call 'plebiscitary' forms of intra-party democracy, in which (unlike assembly-based forms of intra-party democracy) the stages of debate and decision-making are separated and in which party members decide via a secret ballot.

In this paper we focus on whether parties benefit from using a more inclusive selectorate for leadership selection. More specifically, we compare parties that allow all members (fourth rectangle in Figure 1) to select the party leader with parties that restrict this choice to a small group, in this case the party executive (first rectangle). We did not choose for the two extremes on the continuum (respectively one person, and all voters) as they do not occur very often, and in Flanders (the Dutch speaking part of Belgium) not at all, which would render the experiment hypothetical compromising the ecological validity of our study.

Leadership selection procedures and changes therein have attracted considerable scholarly attention in recent years (Pilet \& Cross, 2014; Cross \& Pilet, 2015; Sandri, Seddone \& Venturino, 2015; Chiru et al, 2015 ; Cross and Blais, 2012; Cross \& Katz, 2014; Rahat, Cross, Kenig \& Pruysers, 2016). A first strand of research has focussed on the processes leading to the introduction of changes in the selectorate. Some scholars provide qualitative evidence about the introduction of party primaries in one particular party or country (e.g. Denham, 2009; Lisi, 2010; Quinn, 2010). Others conducted cross-country 
analyses, such as Cross and Blais (2012) who detect decision-makers and stimuli for the adoption of direct member votes in a large number of parties in Westminster systems (the UK, Ireland, Australia, New Zealand and Canada), or try to infer a general pattern from the analysis of parties in one country (Wauters, 2014; Gauja, 2017). All these studies show that changes in leadership selection methods do not just happen, but are, as any other party change, produced by a combination of exogenous factors (i.e. stimuli that provide a reason for change) and endogenous factors (i.e. a coalition of support within the party that makes change possible) (Panebianco, 1988; Harmel and Janda, 1994). In this study, we focus on the stimuli that provide a reason for change. These (exogenous) stimuli could either be external or internal.

External factors confront parties with their weaknesses and induce party elites to change the leadership selection procedure. These stimuli include amongst others membership decline, electoral defeat and losing government participation (Cross \& Blais, 2012; Pilet \& Cross, 2014 ; Chiru et al, 2015). Parties react to these events by introducing organizational changes in order to regain attractiveness among citizens. Democratising leadership selection procedures is then part of a broader strategic plan aimed at improving the performance and the image of a party (Scarrow, 1999; Wauters 2014; Chiru et al, 2015). In this context, the introduction of an inclusive leadership selectorate is supposed to bring the party into the limelight and is often accompanied by a broader media campaign. Scarrow (1999) for instance refers to CDU and SPD, two mainstream parties in Germany that spurred on by a combination of declining party membership and electoral defeats, attempted to turn the tide in the 1990s by giving their members the opportunity to select the party leader. Simultaneously, factors such as electoral defeat and ending up in the opposition also bring about in general a shift in the internal balance of power (i.e. the endogenous factors referred to above), making change in a party possible. Whether more inclusive leadership contests indeed lead to an increased attractiveness of the party is, however, an open question that will be tackled by this study. In Scarrow's example, neither the SPD nor CDU have received much electoral credit for introducing these reforms: their combined vote share continued to fall in the 1990s.

Internal factors point to other sorts of motivation for the introduction of leadership elections. More in particular, these factors refer to a situation in which the party elite itself takes the initiative to introduce inclusive leadership selection methods in order to strengthen their own power. By deducing power from the middle-level elites (which have much power in assembly-based forms of intra-party democracy) and transferring it to the more docile rank-and-file members, party elites get a better grip on who will be elected (Katz \& Mair, 1995; Wauters, 2014). In this case, the leadership selection reform aims to reduce the power of middle-level elites in the party and to strengthen the position of the party 
leader. We will not further investigate these internal factors in this paper, as we focus first and foremost on citizens' reactions, and not on these of party members or party elites.

\section{Consequences of inclusive leadership contests}

Another main area of research on leadership selection processes is dedicated to the analysis of their effects. Broadly speaking, five types of effects (Rahat \& Hazan, 2001) can be distinguished (which have all been studied recently): participation including the type of participants and turnout rates (Seddone \& Venturino, 2013; Wauters, 2015), competitiveness (Kenig, 2009), responsiveness (Lehrer, 2012), representation, in particular the presence of women party leaders (Wauters \& Pilet, 2015; O'Brien, 2015), and performance. In this paper, we focus on the last type of effects, i.e. the effect of leadership selection on performance.

Similar to the reasons to introduce party leadership elections, two kind of indicators of performance can be distinguished: internal and external performance indicators. As for the internal indicator, the basic idea is that more inclusive selection procedures strengthen the legitimacy of the party leader in his/her party. This presumed increase in legitimacy has been evaluated by studying the length of time party leaders retain their position (Ennser-Jedenastik \& Schumacher, 2015; Andrews \& Jackman, 2008). This internal aspect, however, will not be further investigated in this study.

By focusing on the external aspect (i.e. the party's attractiveness to the outside world), we scrutinize the relationship between leadership selection methods and external performance. As argued above, opening up the selectorate for party leadership is believed to be a panacea for parties in crisis, but the question arises whether leadership elections are really able to bring about the desired effects: Do voters consider parties that organize an inclusive leadership contest as more trustworthy? Does the inclusive selection of party leaders pay off in terms of votes for the party and are these parties able to attract more (and new) members? While these effects are often anticipated by the party elite and academics alike (Scarrow, 1999; Cross \& Blais, 2012; Wauters, 2014; for a more sceptical perspective, however: see Katz 2013), they have rarely been investigated systematically. Two studies have made an attempt to evaluate these questions empirically, but, as we will show, some aspects remain understudied. Interestingly, the two studies present different arguments why inclusive selection procedures should boost political parties' appeal.

The first argument is presented in a study by Pedersen and Schumacher (2015) who investigate the effects of leadership selection on electoral performance. Building on the literature about leadership effects in parliamentary elections (Aarts et al, 2013; Garzia, 2012), they test whether the mode of 
selection of the party leader has an impact on the electoral performance of a party. They make a distinction between short-term effects (immediately after the leadership change, measured by a party's score in opinion polls) and long-term effects (the first elections after the leadership change). While their main focus is on leadership renewal and how new party leaders come into power ${ }^{2}$, two of their arguments to expect a positive effect are also relevant for our case.

First, media attention tends to be larger if the selectorate is more inclusive because the selection process is more visible for the public. This higher visibility is obtained because it generally takes longer to select a party leader, and because competition tends to be higher which is interesting for media using a conflict frame (Pedersen \& Schumacher, 2015). A higher media attention can then potentially result, in turn, in more electoral support, although there are also some risks involved (such as negative campaigning by contenders leading to negative media attention and a decrease in support).

Second, the authors theorize that more inclusive selection procedures result in a better electoral performance because more inclusive selectorates will select 'better' leaders. Since rank and file members do not differ enormously from voters in terms of opinions and socio-demographic characteristics, it is more likely that the leaders they select will be more in line with voters' demands (Pedersen \& Schumacher, 2015). A similar reasoning was made by Ramiro (2016) about candidate selection in the Spanish centre-left party PSOE. He found in his empirical analysis a positive link between inclusive procedures and electoral performance.

The results of Pedersen \& Schumacher's empirical analyses, however, show that parties only benefit from more inclusive selectorates in the short term with higher scores in opinion polls, but not in real elections later on. Once media attention has gone, also the effect of the new leader and how (s)he was selected fades away quickly.

Although interesting, this study does not test directly the effect of leadership selection methods itself. It is not about the process of leadership elections, but about its outcomes (more media attention, more performant leaders) and how these influence electoral performance. Moreover, by focussing on new party leaders, incumbent party leaders seeking re-election are excluded, even when they are selected by inclusive methods. In addition, also the kind of party leader (and the performance of other parties and their leaders) might influence the outcome of the analysis. By using an experimental design, we try to overcome that these intermediary factors confound the results.

\footnotetext{
${ }^{2}$ They take party leaders as unit of analysis instead of party leadership selections. Therefore, elections in which party leaders are re-elected are not included in their analysis.
} 
Another argument why inclusive selectorates should yield positive external effects is presented in the study of Shomer, Put and Gedalya-Lavy (2016). While these authors focus on candidate selection methods, their findings can easily be translated to leadership selection processes as well. The external effect they analyse is citizens' level of trust in political parties (another element parties are struggling with). They find that more inclusive ${ }^{3}$ selectorates result in higher levels of trust in political parties among citizens. The main argument put forward to support these results is procedural fairness. This concept denotes that citizens who could have a voice in a decision-making process, will be satisfied with the process and the political system (even if they do not obtain their preferred outcome). Procedural fairness is argued to trump a potential negative effect that might result from intra-party conflict associated with more inclusive selection mechanisms. While this represents an interesting study, it has to be noted that the authors focus on trust in parties in general, and that they do not analyse whether one particular party that is using inclusive leadership methods benefits (more) from higher trust levels (as trust in parties in general is measured). Moreover, the causal mechanism might be reverse: citizens with higher levels of trust in political parties are more likely to join parties that have inclusive candidate selection methods.

Drawing on these studies and inspired by the procedural fairness argument (Grimes, 2006 ; Marien \& Kern, 2018), we theorize that inclusive leadership contests are perceived as more fair (than exclusive ones), and therefore should lead to higher levels of trustworthiness and attractiveness. We base our argument on the assumption originating from the procedural fairness theory (Fehr and Schmidt 1999; Tyler 2011) that citizens value fair selection procedures. The procedural fairness theory presumes that citizens do not only care about the outcome of decisions but also about how these decisions were made. The core idea is that citizens perceive decision making procedures as more fair when they were involved in the process. It is argued that this positive perception can even mitigate negative outcome effects (i.e. the effect of having obtained an unfavourable decision) (e.g. Tyler 2011; Grimes 2006). We argue that, as opposed to elite arrangements behind closed doors, leadership elections among party members appear rather open and transparent and hence as comparatively fair, which will increase trustworthiness and attractiveness.

In order to apply the procedural fairness argument to the context of leadership contests, we need to assume that citizens perceive more inclusive selection procedures as fair, although participation in leadership contests is still restricted to party members (in most parties and in our experimental design here). We have two reasons for the plausibility of this assumption. First, citizens tend to perceive

\footnotetext{
${ }^{3}$ They also analyse the effect of centralization or decentralization of selection procedures, but as this is less relevant for our purposes, we will not further discuss this here.
} 
political elites as detached from the rest of the population (Krouwel \& Abts 2007) and they should consequently prefer 'ordinary' party members to take crucial decisions over more exclusive actors. Second, this reasoning is supported by empirical research that demonstrates that large parts ${ }^{4}$ of the electorate prefer more inclusive selection procedures that involve either party members or even all voters (Close, Kelbel \& van Haute, 2017). Based on this reasoning we argue that citizens should perceive political parties with inclusive leadership as more attractive than parties in which the party elite decides upon leadership. We furthermore theorize that this stronger appeal should not only be reflected in higher levels of perceived trustworthiness of these parties but also translate into a higher propensity to (a) vote for such a party and to (b) become a member of such a party. Our hypotheses hence read as follows:

H1: Citizens perceive political parties with inclusive leadership selection procedures as more trustworthy than parties in which party elites decide upon leadership.

$\mathrm{H} 2$ : Citizens are more willing to vote for political parties with inclusive leadership selection procedures than for parties in which party elites decide upon leadership.

H3: Citizens are more willing to become a member of political parties with inclusive leadership selection procedures than of parties in which party elites decide upon leadership.

While we argue that there is a positive effect of inclusive leadership selection procedures on the parties' perceived trustworthiness, the willingness to vote for the party as well as the willingness to join the party, we expect that trustworthiness is more strongly affected than the willingness to vote for or join the party. This argument is based on the reasoning that attitudes change more readily than behaviour (Gershuny 2001) and the claim that political participation is determined by positive attitudes (predispositions) towards politics, such as political interest, efficacy and trust (Ajzen \& Fishbein, 1977). We furthermore expect the effect to be smallest for becoming a party member because, as compared to simply voting for a party, party membership requires a formal, long term engagement - something that post-materialist citizens increasingly refrain to do, as they prefer more individualised forms of engagement in politics (Inglehart, 1997).

\footnotetext{
${ }^{4}$ We should note, however, that according to the study of Close et al (2017) citizens' preferences are not homogenous in respect to candidate selection procedures: while about two-thirds of the citizens do prefer inclusive methods (either voters or members who decide), still another third of them prefer other methods (involving delegates, party leaders or drawing lots).
} 
The argument that fair procedures should enhance a political party's trustworthiness and attractiveness is expected to hold for all citizens. However, it is possible that the type of selection procedure matters only for specific types of citizens, namely those that are ideologically close to the party. Citizens whose policy preferences are not or only marginally reflected by a specific political party, might not consider the party as trustworthy or attractive, independent on how they select their leader. This reasoning is backed by the finding that ideological considerations play a major role when evaluating political parties (van der Brug et al, 2000; van der Eijk et al, 2005,). In fact, as van der Brug (2004, p. 225) shows " [...] ideological proximity is the most important determinant of voting behaviour". A similar line of reasoning might hold for citizens who are characterized by low levels of political interest. To those citizens, parties might be untrustworthy and unattractive independent of the inclusiveness of the leadership selection process. In our study we will account for this possibility.

To test the three hypotheses we designed a vignette experiment and tested it among Flemish citizens. In the following section, we elaborate on the design of our experiment.

\section{Methodology}

The experiment ${ }^{5}$ was conducted online among Flemish citizens whom we drew from iVOX's internetbased access panel. With more than 150,000 potential respondents, iVOX' panel represents the largest online panel in Flanders (one of the major regions in Belgium). In order to obtain respondents that are as representative for the Flemish population as possible, we set quota on gender and age (interlocked) and on the level of education. The questionnaire started with a description of a fictitious party followed by questions about the trustworthiness of this party, respondents' willingness to vote for this party and their wiliness to join the party. Between January, $15^{\text {th }}$ and February, $22^{\text {nd }} 2019,2,338$ citizens completed this questionnaire.

Almost all Belgian parties (except for the radical right VB and the radical left PVDA-PTB) have evolved from an assembly-based system in which party delegates selected the party leader to a plebiscitary system in which all members are allowed to vote (Pilet \& Wauters, 2014). Initially after WW II, party leaders were selected by party congresses that were composed of delegates of the regional (or even local) sections of the party. Rank and file members at the regional or local level selected delegates to represent them on a national party conference, which decided on the party leader. This procedure was

\footnotetext{
5 The design of the experiment was pre-registered with EGAP prior to data collection
} (http://egap.org/registration/5430). 
gradually democratized especially in the course of the 1990s (Pilet \& Wauters, 2014) and now in almost all parties, party members select the party leader in direct elections. It comes then as no surprise that in cross-national perspective, Belgian parties score high on the plebiscitary intra-party democracy index developed by Poguntke, Scarrow, and Webb (2016). Belgium provides thus a specific context as in reality almost all parties use a direct member vote to select their party leader. This means that using an inclusive selectorate does not allow parties anymore to really distinguish themselves from others. But we argue that the opposite is also true: using a rather exclusive way of selecting the party leader should attract the attention in such a context, and could have a negative impact. In that sense, we are confident that our research design is able to capture the effect of using an inclusive or exclusive method of leadership selection.

We opted for a between-subject experimental design. The two different selectorates deciding on leadership selection (party executive board versus all party members) forms the between-factor. However, we provided two party profiles for each condition: one party profile with rather leftist ideological positions and one rather rightist party profile. This combination led to four different conditions (rightist and closed selectorate, rightist and open selectorate, leftist and closed selectorate, leftist and open selectorate) that were randomly assigned to participants ${ }^{6}$. As Table A.1 in the appendix shows, participants clearly positioned the two party profiles differently, positioning the party with the rightist profile on the right side of the ideological spectrum, and the party with the leftist characteristics on the left side, which was exactly our goal.

The use of two ideologically different parties functions as a robustness check, as we expect our hypotheses to hold for both ideological profiles. By using hypothetical parties, we eliminate to some extent the possibility that personal preferences or attitudes about the contemporary public debate influence participants' opinion. It also offers the opportunity to restrict party information and to control for moderating variables (see also Campbell \& Cowley, 2014; Wauters \& Devroe, 2018). Here in particular, this approach allows to exclude the impact of media effects and of the quality of the elected party leader (Pedersen \& Schumacher, 2015) on the consequences of the selection method. Conducting the survey online and anonymously offers an accessible and affordable way of datacollection while reducing social desirability bias which could arise when respondents are faced with an interviewer.

Each party was introduced via a short fact sheet (see Table A.3 in the appendix), which contained the number of party members (the same for all parties), the mode of selection of the party leader (either

\footnotetext{
${ }^{6}$ Evidence for random assignment is provided in Table A. 2 in the appendix.
} 
by the party executive board or by all party members) and stances of the party on four policy issues (either a consistent leftist profile including taking care of life-work balance, stimulating ecological agriculture, introducing tax reductions for low incomes, and stimulating prevention in criminal policy, or a consistent rightist profile including stimulating entrepreneurship, activating and controlling the unemployed, investigating the feasibility of new environmental rules before introducing them, and more powers for police forces). The second element (i.e. the mode of leadership selection) represents the treatment and central focus of this study. We opted for two actors that clearly differ from each other in terms of inclusiveness of the selectorate (Rahat \& Hazan, 2001): while the party executive board is a rather exclusive selectorate, party members are at the more inclusive side of this continuum. At the same time, we did not pick the most inclusive form of selectorate, selection by all voters, because this option would not be realistic in the Belgian context.

After presenting each party profile, respondents were asked to position themselves on three 11-point scales referring respectively to the level of trust they had in that party (from $0=$ very low to $10=$ complete trust), the probability to vote for this party (from $0=$ highly unlikely to $10=$ highly likely) and the probability to become member of that party (again from $0=$ highly unlikely to $10=$ highly likely). These three variables represent the dependent variables of our analysis. Furthermore, we asked them to place the presented parties on an ideological left-right scale, ranging from 0 (= left) to 10 (= right).

Next, by asking who selected the party leader, we included a manipulation check, which allows us test whether respondents have read the party profile with enough attention. We also included some covariates (respondents' level of political interest, trust in the federal government and self-placement on an ideological left-right scale) and socio-demographics (sex, age, level of education, hometown).

\section{Results}

In a first step, we look at the distribution of our dependent variables. As Table 1 shows, the average trust score for the four fictitious parties is 6.275 , which is a bit higher than the average level of Belgian citizens. $^{7}$ Regarding the fictitious parties' appeal, it shows that respondents are more reluctant concerning their probability to join any of the four parties (average of 2.315) as compared to voting for these parties (average of 5.652). But again, this is little surprising given that becoming a party member is a lot more demanding (in terms of time and effort) than voting for a party.

\footnotetext{
7 In the 8th round of the European Social Survey (2016), the average trust score that Belgian citizens assigned to political parties was only 4.038 (design weights applied)
} 
Table 1. Distribution of dependent variables among participants

\begin{tabular}{llllll}
\hline Variable & Obs. & Mean & Std. Dev & Min. & Max \\
\hline Trust in party & 2305 & 6.275 & 1.772 & 0 & 10 \\
Willingness to vote for party & 2299 & 5.652 & 2.318 & 0 & 10 \\
Willingness to become member of the party & 2292 & 2.315 & 2.483 & 0 & 10 \\
\hline
\end{tabular}

In a second step, we tackle our hypotheses by distinguishing between those who received the vignette with the inclusive selection procedure (i.e. party leader selected by all party members) and those who received the vignette with the exclusive selection procedure (i.e. party leader selected the party executive board). We distinguish between leftist and rightist parties.

Table 2. Comparison of trustworthiness, willingness to vote for and become a member of a party

\begin{tabular}{|c|c|c|c|}
\hline & $\begin{array}{l}\text { Inclusive } \\
\text { Selection }\end{array}$ & $\begin{array}{l}\text { Exclusive } \\
\text { Selection }\end{array}$ & Difference \\
\hline Trust in the rightist party & $\begin{array}{l}6.262 \\
(554)\end{array}$ & $\begin{array}{l}6.229 \\
(572)\end{array}$ & 0.033 \\
\hline Willingness to vote for the rightist party & $\begin{array}{l}5.580 \\
(552)\end{array}$ & $\begin{array}{l}5.521 \\
(570)\end{array}$ & 0.059 \\
\hline $\begin{array}{l}\text { Willingness to become a member of the } \\
\text { rightist party }\end{array}$ & $\begin{array}{l}2.319 \\
(551)\end{array}$ & $\begin{array}{l}2.247 \\
(567)\end{array}$ & 0.072 \\
\hline Trust in the leftist party & $\begin{array}{l}6.274 \\
(585)\end{array}$ & $\begin{array}{l}6.332 \\
(594)\end{array}$ & -0.058 \\
\hline Willingness to vote for the leftist party & $\begin{array}{l}5.729 \\
(583)\end{array}$ & $\begin{array}{l}5.769 \\
(594)\end{array}$ & -0.040 \\
\hline $\begin{array}{l}\text { Willingness to become a member of the } \\
\text { leftist party }\end{array}$ & $\begin{array}{l}2.281 \\
(581)\end{array}$ & $\begin{array}{l}2.410 \\
(593)\end{array}$ & -0.129 \\
\hline
\end{tabular}

Note: Differences are tested with independent sample t-tests. $\mathrm{N}$ in parentheses. Sign.:*** $\mathrm{p}<0.001,{ }^{* *} p<0.01$, $* p<0.05$.

First, we focus on respondents' evaluation of the fictitious rightist parties. We rely on independent samples t-tests to compare respondents' evaluation of parties with inclusive and exclusive leadership selection. Concerning the levels of trust in rightist parties there was no significant difference between the respondents who received the inclusive condition $(M=6.3, S D=1.9)$ and respondents who evaluated the exclusive condition $(M=6.2, S D=2.0)$. Also regarding their willingness to vote for a rightist party, respondents who received the inclusive condition $(M=5.6, S D=2.5)$ did not differ significantly from respondents who received the exclusive condition $(M=5.5, S D=2.5)$. Finally, we 
compared their self-declared willingness to become a member of the rightist party that they evaluated. Again, in contrast to our hypothesis, no significant difference was found between respondents who received the vignette with the more inclusive process $(M=2.3, S D=2.5)$ and respondents who received the party description with the exclusive selection process $(M=2.2, S D=2.5)$. This analysis of selection procedures in parties with a rightist profile hence does not support any of our three hypotheses.

The analysis of inclusive versus exclusive leadership selection procedures among leftist parties yields similar results. When evaluating the trustworthiness of leftist parties, the participants of our experiment were, in contrast to our hypothesis, not significantly more positive about parties with inclusive procedures $(M=6.3, S D=1.5)$ as compared to parties in which the executive board selects the party leader ( $M=6.3, S D=1.6)$. Also, just as with rightist parties, the selection process does not appear to affect the electoral fortune of the leftist parties, as we find no significant difference between the scores for the party with the inclusive procedure $(M=5.7, S D=2.1)$ and the party with the exclusive selection procedures $(M=5.8, S D=2.1)$. Finally, also when studying leftist parties, no evidence is found to support $\mathrm{H} 3$, because also among leftists parties no difference was found concerning the selfindicated willingness to join the party. Participants' willingness to join the part did not differ between those who were exposed to the inclusive condition $(M=2.3, S D=2.4)$ from those who received the exclusive version of the vignette $(M=2.4, S D=2.5)$. Consequently, based on this analysis, we cannot support any of our three hypotheses. These results hold for both types of party profiles.

The analysis reported in Table 2 represents the intent-to treat analysis (ITT), as it was conducted on the basis of all participants to whom we had successfully delivered the treatment (i.e. who were confronted with one of the four party profiles). However, based on our manipulation check question we know that about 35 percent of the respondents did not take the treatment (or at least were not able to recall who selected the party leader in the party they just read about). We therefore repeated our analysis, excluding those respondents who failed to answer this question correctly (Table 3). ${ }^{8}$

\footnotetext{
${ }^{8}$ As our data shows (Table A.4 in the Appendix) the percentage of participants passing the manipulation check differs substantively between the different party profiles. About 80 percent of the participants who were confronted with the open electoral procedure passed the manipulation check, whereas for the participants who evaluated the parties with the party leader being appointed by the party executive, this in only about 54 percent. This difference is statistically significant as Table A.5 shows. There are different possible explanations for this finding. First, it is possible that having read about an inclusive procedure was better recalled than reading about a rather closed process. Second, possibly some participants might have just guessed and as inclusive leadership selection procedures are the norm in the Belgian party system, participants who had received the inclusive vignettes were just lucky that this norm corresponds with the party profile they had seen.
} 
Table 3. Comparison of trustworthiness, willingness to vote for and become a member of a party, only among respondents who took the treatment

\begin{tabular}{|c|c|c|c|}
\hline & $\begin{array}{l}\text { Inclusive } \\
\text { Selection }\end{array}$ & $\begin{array}{l}\text { Exclusive } \\
\text { Selection }\end{array}$ & Difference \\
\hline Trust in the rightist party & $\begin{array}{l}6.354 \\
(444)\end{array}$ & $\begin{array}{l}6.196 \\
(301)\end{array}$ & 0.158 \\
\hline Willingness to vote for the rightist party & $\begin{array}{l}5.619 \\
(444)\end{array}$ & $\begin{array}{l}5.462 \\
(301)\end{array}$ & 0.157 \\
\hline $\begin{array}{l}\text { Willingness to become a member of the } \\
\text { rightist party }\end{array}$ & $\begin{array}{l}2.320 \\
(444)\end{array}$ & $\begin{array}{l}2.060 \\
(301)\end{array}$ & 0.260 \\
\hline Trust in the leftist party & $\begin{array}{l}6.309 \\
(466)\end{array}$ & $\begin{array}{l}6.382 \\
(319)\end{array}$ & -0.073 \\
\hline Willingness to vote for the leftist party & $\begin{array}{l}5.760 \\
(466)\end{array}$ & $\begin{array}{l}5.749 \\
(319)\end{array}$ & 0.011 \\
\hline $\begin{array}{l}\text { Willingness to become a member of the } \\
\text { leftist party }\end{array}$ & $\begin{array}{l}2.333 \\
(466)\end{array}$ & $\begin{array}{l}2.411 \\
(319)\end{array}$ & -0.078 \\
\hline
\end{tabular}

Note: We only consider participants who answered the manipulation check correctly. These were 1,5030 out of the 2,338 respondents. Differences are tested with independent sample t-tests. $\mathrm{N}$ in parentheses. Sign..*** $\mathrm{p}<0.001,{ }^{* *} \mathrm{p}<0.01,{ }^{*} \mathrm{p}<0.05$.

As Table 3 shows, also when excluding respondents who did not take the treatment, none of our hypotheses can be supported. Apparently, opening up the leadership selection procedure does not pay off - neither in terms of trustworthiness evaluations nor in terms of appeal to voters and potential members.

Whereas this result seems to hold for respondents in general (independent of whether they passed the manipulation check or not), it is still possible that the type of leadership selection does matter to certain types of citizens. In order to test for this possibility we ran some additional analyses and tested whether the type of leadership selection matters to respondents (1) who are ideologically close to the presented party and (2) who have a high level of political interest. The analysis investigating the effect of leadership selection conditioned by ideological distance is presented in Table 4 for the rightist party profile and in Table 5 for the leftist party profile. ${ }^{9}$ The analysis for potentially conditioning effect of political interest can be found in the appendix (Table A.6).

\footnotetext{
${ }^{9}$ The ideological distance of a respondent to the political party he or she evaluated was measured by taking the square root of the difference between the ideological placement of the party as estimated by the respondents, and their own ideological self-placement on a left-right scale.
} 
Table 4. The effect of intraparty democracy on trustworthiness and appeal of the rightist party

\begin{tabular}{lcccccc}
\hline & \multicolumn{2}{c}{ Trust } & \multicolumn{2}{c}{ Wightist Party Profile } & & \\
\hline & $\mathrm{I}$ & $\mathrm{II}$ & $\mathrm{III}$ & $\mathrm{IV}$ & $\mathrm{V}$ & $\mathrm{V}$ VI \\
\hline Open election & 0.088 & -0.145 & 0.061 & -0.069 & 0.173 & 0.130 \\
& $(0.124)$ & $(0.176)$ & $(0.156)$ & $(0.221)$ & $(0.172)$ & $(0.244)$ \\
Level of education & $-0.099^{* *}$ & $-0.101^{* *}$ & -0.079 & $-0.080^{*}$ & $-0.205^{* * *}$ & $-0.206^{* * *}$ \\
& $(0.032)$ & $(0.032)$ & $(0.041)$ & $(0.041)$ & $(0.045)$ & $(0.045)$ \\
Political interest & $0.052^{*}$ & $0.054^{*}$ & 0.034 & 0.035 & $0.208^{* * *}$ & $0.208^{* * *}$ \\
& $(0.023)$ & $(0.023)$ & $(0.029)$ & $(0.029)$ & $(0.032)$ & $(0.032)$ \\
Ideological & $-0.476^{* * *}$ & $-0.548^{* * *}$ & $-0.694^{* * *}$ & $-0.735^{* * *}$ & $-0.397^{* * *}$ & $-0.410^{* * *}$ \\
distance & $(0.030)$ & $(0.049)$ & $(0.038)$ & $(0.062)$ & $(0.042)$ & $(0.068)$ \\
Ideological distance* & & 0.115 & & 0.065 & & 0.0211 \\
Open election & & $(0.062)$ & & $(0.078)$ & & $(0.086)$ \\
Intercept & $7.773^{* * *}$ & $7.929 * * *$ & $7.420^{* * *}$ & $7.507 * *$ & $3.520 * * *$ & $3.549 * *$ \\
& $(0.331)$ & $(0.341)$ & $(0.415)$ & $(0.428)$ & $(0.458)$ & $(3.549)$ \\
\hline$N$ & 740 & 740 & 740 & 740 & 740 & 740 \\
adj. $R^{2}$ & 0.259 & 0.261 & 0.315 & 0.314 & 0.158 & 0.156 \\
\hline
\end{tabular}

Note: Unstandardized coefficients with standard errors in parentheses. ${ }^{*} p<0.05,{ }^{* *} p<0.01,{ }^{* * *} p<0.001$.

Both Table 4 and Table 5 show that although the ideological distance to the party affects the perception of trustworthiness and the willingness to vote for and join the presented party negatively in all models, the interaction between ideological distance and leadership selection is not significant in any model. We can hence conclude that the existence of an open leadership selection does not affect respondents' perception of trustworthiness and appeal - not even when citizens are ideologically close to the party, nor when they are highly interested in politics as Table A.6 in the appendix shows.

Table 5. The effect of intraparty democracy on trustworthiness and appeal of the leftist party

\begin{tabular}{lcccccc}
\hline & \multicolumn{7}{c}{ Trust } & \multicolumn{2}{c}{ Willingness to vote } & \multicolumn{2}{c}{ Willingness to join } \\
\hline & $\mathrm{I}$ & $\mathrm{II}$ & $\mathrm{III}$ & $\mathrm{IV}$ & $\mathrm{V}$ & $\mathrm{VI}$ \\
\hline Open elections & -0.079 & -0.229 & 0.013 & -0.199 & -0.057 & -0.418 \\
& $(0.106)$ & $(0.156)$ & $(0.141)$ & $(0.209)$ & $(0.172)$ & $(0.253)$ \\
Level of education & 0.003 & 0.006 & -0.014 & -0.010 & $-0.118^{* *}$ & $-0.111^{*}$ \\
& $(0.027)$ & $(0.027)$ & $(0.037)$ & $(0.037)$ & $(0.044)$ & $(0.045)$ \\
Political interest & $0.056^{* *}$ & $0.055^{* *}$ & 0.052 & 0.051 & $0.200^{* * *}$ & $0.198^{* * *}$ \\
& $(0.021)$ & $(0.021)$ & $(0.028)$ & $(0.028)$ & $(0.033)$ & $(0.033)$ \\
Ideological distance & $-0.214^{* * *}$ & $-0.260^{* * *}$ & $-0.412^{* * *}$ & $-0.476^{* * *}$ & $-0.277^{* * *}$ & $-0.387^{* * *}$ \\
& $(0.028)$ & $(0.045)$ & $(0.037)$ & $(0.060)$ & $(0.045)$ & $(0.072)$ \\
Ideological distance* & & 0.074 & & 0.104 & & 0.179 \\
Open election & & $(0.057)$ & & $(0.076)$ & & $(0.092)$ \\
Intercept & & & & & \\
& & & & & & \\
& $\left(0.267^{* * *}\right.$ & $6.536^{* * *}$ & $6.406^{* * *}$ & $6.504 * * *$ & $2.845^{* * *}$ & $3.012^{* * *}$ \\
& & $(0.277)$ & $(0.364)$ & $(0.371)$ & $(0.442)$ & $(0.450)$ \\
\hline
\end{tabular}




\begin{tabular}{lcccccc}
\hline$N$ & 780 & 780 & 780 & 780 & 780 & 780 \\
adj. $R^{2}$ & 0.071 & 0.071 & 0.134 & 0.135 & 0.082 & 0.085 \\
\hline
\end{tabular}

Note: Unstandardized coefficients with standard errors in parentheses. ${ }^{*} p<0.05,{ }^{* *} p<0.01,{ }^{* * *} p<0.001$.

\section{Conclusion and discussion}

The past few decades, a considerable number of political parties have opened up their leadership selection process by giving rank and file members a say through a direct member vote. Internal factors (strengthening leaders' power within the party) and external factors (making the party more attractive) have been detected as drivers for this organizational change.

Rather remarkably, only a few systematic tests have been conducted about whether the intended effects are also realized. We have undertaken this endeavour by setting up an experimental design among citizens. We focus on direct external effects, and more in particular on whether inclusive selection procedures makes a party more trustworthy and more attractive to voters and potential members. There are several reasons to assume such an effect: apart from indirect effects such as more media attention, there is the fact that party elites introducing more inclusive selectorates believe that these effects will come about, and the theoretical argument of 'procedural fairness'. Inclusive procedures to take decisions (such as a direct member vote) are believed to increase the sense of fairness among people, and will therefore presumably (regardless of the outcome) increase the level of trust people have in this procedure and organisation and will increase its attractiveness.

The results of our empirical analysis, however, clearly show that there is no effect of selecting the party leader by all party members. Neither trustworthiness nor attractiveness towards voters and potential members are higher in a party with an inclusive selectorate (compared to a party with an exclusive selectorate). This lack of an effect remains even if we only compare voters that agree with a party's views. This means that electing a party leader in a direct member vote has only an indirect short-term effect: as Pedersen \& Schumacher (2015) have demonstrated, parties electing their leader in a direct member vote experience a temporary rise in their opinion poll scores. This temporary effect could be explained by the indirect effect of media attention around this direct member vote and the new face of the party leader that is launched, rather than by the inclusive selection procedure itself. Our survey experiment allowed to disentangle direct and indirect effects, and we clearly demonstrate that there is no direct effect of inclusive procedures on any of the three success indicators we included (trustworthiness, attractiveness towards voters and potential members).

Although our (non-)findings are very robust, we have to bring in four nuances to the debate. 
First, the procedural fairness argument pertains first and foremost to those who are involved themselves in the procedure, in this case party members, while we conducted research among citizens. We have, however, argued that also for people not directly involved in the selection procedure, the selection method can be relevant. Previous research indeed demonstrated that a large part of the voters prefer inclusive selection procedures in political parties and that they are likely to have more trust in rank and file members who are more similar to them than party elites. Although we did not find any effect among voters, we cannot completely rule out that there is an effect among party members, who are directly involved in the leadership selection. In that case, inclusive selection procedures might not lead to the influx of new members, but to keeping existing members on board. More specific research on party members should check whether this is indeed the case.

Second, the focus of this study is on Belgium, which is an extra-ordinary case in cross-country perspective as (almost) all parties there use a direct member vote to select their party leader. One could argue that due to the pervasiveness of this procedure citizens are used to it and parties cannot make a difference anymore when organising inclusive leadership contests. This is of course true, but one could also reverse the argument by stating that in such a context a party that is using an exclusive selectorate attracts the attention and risks to be punished by voters. This, however, is something we could not observe in our study.

Third, the underlying assumption in our reasoning to expect a positive effect of inclusive leadership selection methods, is that voters perceive this procedure as more 'fair' than more exclusive methods. We do not test this assumption in this study, however. Moreover, the specific Belgian context casts some doubts about the plausibility of this assumption. Apart from the argument that (almost) all parties use inclusive methods (see above) rendering the fairness of this kind of methods less noticeable, there is also the fact that in almost half of all Belgian inclusive leadership contests only one candidate takes part (Pilet and Wauters, 2014). Party members can only approve or disapprove this single candidate, which reduces the impact members can have and also potentially diminishes the sense of fairness associated with this method. These two factors could be an explanation for the lack of effects that we find in this study.

Fourth, we have shown that our sample seems to have more trust in politics than the average Belgian citizen. While this arguably limits the ecological validity of our experiment, it should not affect the internal validity of the relationship between intra-party democracy and citizens' perceptions of trustworthiness and attractiveness of the party.

Despite these nuances, we can state that there are no direct effects of inclusive leadership selection procedures on trustworthiness and attractiveness of the party. The question is then why parties continue to use them. At least at the time of the introduction of these direct member votes, party 
elites were (in their discourse) convinced that this would positively affect the image of the party. Either these party elite members ware naïve or badly informed, or their discourse differed from their real intentions namely increasing their own influence in the party to the detriment of middle-level elites (Schumacher and Giger, 2018; Wauters, 2014). In the latter case, internal and indirect factors are more important than external ones for the introduction and continuation of inclusive selectorates. Another explanation might be that party leaders aim for effects originating from changes in selection methods (which was not tested here as we analysed two specific, but fictuous parties at only one point in time). It might be that positive effects occur only once (when changes are introduced). Afterwards, these procedures (such as inclusive leadership selection methods) remain in function, as once they are launched, it is difficult to remove them again. 


\section{List of references}

Aarts K, Blais A and Schmitt H (2013) Political leaders and democratic elections. Oxford: Oxford University Press.

Ajzen I and Fishbein M (1977) Attitude-Behavior Relations: A Theoretical Analysis and Review of Empirical Research. Psychological Bulletin 84 (5): 888-918.

Andrews JT and Jackman RW (2008) If winning isn't everything, why do they keep score? Consequences of electoral performance for party leaders. British Journal of Political Science 38(4): 657-675.

Campbell R and Cowley P (2014) What voters want: Reactions to candidate characteristics in a survey experiment. Political Studies 62(4): 745-765.

Carman C (2010) The process is the reality: Perceptions of procedural fairness and participatory democracy. Political Studies 58(4): 731-751.

Chiru M, Gauja A, Gherghina S and Rodriguez-Teruel J (2015) Explaining change in party leadership selection rules. In: Cross W and Pilet J-B (eds) The Politics of Party Leadership: A Cross-National Perspective. Oxford: Oxford University Press, pp. 31-49.

Close C, Kelbel C and van Haute E (2017) What Citizens Want in Terms of Intra-Party Democracy: Popular Attitudes towards Alternative Candidate Selection Procedures. Political Studies 65(3): 646664.

Cross W and Blais A (2012) Who selects the party leader? Party Politics 18(2): 127-150.

Cross W and Katz RS (eds) (2013) The challenges of intra-party democracy. Oxford: Oxford University Press.

Cross W and Pilet J-B (eds) (2015) The Politics of Party Leadership: A Cross-National Perspective. Oxford: Oxford University Press.

Denham A (2009) From grey suits to grass roots: Choosing Conservative leaders. British Politics 4(2): 217-235.

Devroe R and Wauters B (2018) Political Gender Stereotypes in a List-PR System with a High Share of Women MPs: Competent Men versus Leftist Women? Political Research Quarterly 71(4): 788-800.

Ennser-Jedenastik L and Schumacher G (2015) Why Some Leaders Die Hard (and Others Don't): Party Goals, Party Institutions, and How They Interact. In: Pilet, J-B and Cross W (eds) The Politics of Party Leadership: A Cross-National Perspective. Oxford: Oxford University Press, pp. 107-127. 
Fehr E and Schmidt KM (1999) A Theory of Fairness, Competition, and Cooperation. Quarterly Journal of Economics 114(3): 817-868.

Garzia D (2012) Party and leader effects in parliamentary elections: Towards a reassessment. Politics 32(3): 175-185.

Gauja A (2017) Party Reform. The Causes, Challenges and Consequences of Organizational Change. Oxford: Oxford University Press

Gershuny J (2001) Changing times. New York: Oxford University Press.

Grimes M (2006) Organizing consent: The role of procedural fairness in political trust and compliance. European Journal of Political Research 45(2): 285-315.

Harmel R and Janda K (1994) An Integrated Theory of Party Goals and Party Change. Journal of Theoretical Politics 6(3): 259-287.

Inglehart R (1997) Modernization and Postmodernization. Princeton: Princeton University Press.

Katz RS (2013) Should we believe that improved intra-party democracy would arrest party decline?. In: Cross W and Katz RS (eds) The challenges of intra-party democracy. Oxford: Oxford University Press, pp. 49-64.

Katz RS and Mair P (1995) Changing Models of Party Organisation and Party Democracy: The Emergence of the Cartel Party. Party Politics 1(1): 5-28.

Kenig O (2009) Democratization of party leadership selection: Do wider selectorates produce more competitive contests? Electoral Studies 28(2): 240-247.

Krouwel A and Abts K (2007) Varieties of Euroscepticism and Populist Mobilization: Transforming Attitudes from Mild Euroscepticism to Harsh Eurocynicism. Acta Politica 42(2-3): 252-270.

Lehrer R (2012) Intra-Party Democracy and Party Responsiveness. West European Politics 35(6): 12951319.

Lisi M (2010) The democratisation of party leadership selection: the Portuguese experience. Portuguese Journal of Social Science 9(2): 127-149.

Marien S and Kern A (2018) The Winner Takes It All: Revisiting the Effect of Direct Democracy on Citizens' Political Support. Political Behavior 40(4): 857-882.

O'Brien DZ (2015) Rising to the Top: Gender, Political Performance, and Party Leadership in Parliamentary Democracies. American Journal of Political Science 59(4): 1022-1039.

Panebianco A (1988) Political parties: organization and power. Cambridge: Cambridge University Press. 
Pedersen HH and Schumacher G (2015) Do Leadership Changes Improve Electoral Performance? In: Cross W and Pilet JB (eds) The Politics of Party Leadership: A Cross-National Perspective. Oxford: Oxford University Press, pp. 149-164.

Pilet J-B and Cross W eds (2014) The Selection of Political Party Leaders in Contemporary Parliamentary Democracies. A Comparative Study. London: Routledge.

Pilet J-B and Wauters B (2014) The selection of party leaders in Belgium. In Pilet J-B and Cross W (eds) The Selection of Political Party Leaders in Contemporary Parliamentary Democracies. A Comparative Study. London: Routledge, pp. 30-46.

Poguntke T, Scarrow SE and Webb P (2016) Party rules, party resources and the politics of parliamentary democracies:How parties organize in the 21st century. Party Politics 22(6): 661-678

Quinn T (2010) Membership ballots in party leadership elections in Britain. Representation 46(1): 101117.

Rahat G and Hazan RY (2001) Candidate selection methods an analytical framework. Party Politics 7(3): 297-322.

Rahaț G, Cross W, Kenig O and Pruysers S (2016) Promise and Challenge of Party Primary Elections: A Comparative Perspective. Montreal: McGill-Queen's University Press.

Ramiro, L (2016) Effects of party primaries on electoral performance: The Spanish Socialist primaries in local elections. Party Politics 22(1): 125-136.

Sandri G, Seddone A and Venturino F (eds) (2015) Party primaries in comparative perspective. Farnham: Ashgate.

Scarrow SE (1999) Parties and the Expansion of Direct Democracy Who Benefits? Party Politics 5(3): 341-362.

Schumacher G and Giger N (2018) Do leadership-dominated parties change more? Journal of Elections, Public Opinion and Parties 28: 349-360.

Seddone A and Venturino F (2013). Bringing voters back in leader selection: the open primaries of the Italian Democratic Party. Modern Italy 18(3): 303-318.

Shomer Y, Put G-J and Gedalya-Lavy E (2016) Intra-party politics and public opinion: How candidate selection processes affect citizens' satisfaction with democracy. Political Behavior 38(3): 509-534.

Tyler TR (2011) Why People Cooperate: The Role of Social Motivation. Princeton: Princeton University Press. 
van der Brug W (2004) Issue ownership and party choice. Electoral Studies 23: 209-233.

van der Brug W , Fennema M and Tillie J (2000) Anti-immigrant Parties in Europe: Ideological or Protest Vote. European Journal of Political Research 37: 77-102.

van der Eijk C, Schmitt H and Binder T (2005) Left-Right Orientations and Party Choice. In: Thomassen J (ed) The European voter : a comparative study of modern democracies. Oxford: Oxford University Press, pp. 166-190.

Wauters B (2014) Democratising Party Leadership Selection in Belgium: Motivations and Decision Makers. Political Studies 62(S1): 61-80.

Wauters B (2015) Turnout rates in closed party leadership primaries: flash and fade out? Government and Opposition 50(2): 218-239.

Wauters B and Pilet J-B (2015) The selection of female party leaders. Does the selectorate make a difference? In: Cross W and Pilet J-B (eds) The Politics of Party Leadership: A Cross-National Perspective. Oxford: Oxford University Press, pp. 73-89. 


\section{Appendix}

<<Table A1- Table A6 here >> 